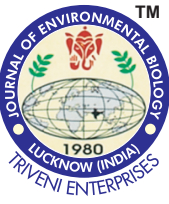

\title{
Potential of hexavalent chromium-resistant rhizosphere bacteria in promoting plant growth and hexavalent chromium reduction
}

\section{Authors Info \\ Mohd. A. Kamaruzzaman"*, S.R.S. Abdullah', H.A. Hasan', M. Hassan', M. Idris ${ }^{3}$ and Nur 'Izzati Ismail \\ ${ }^{1}$ Research Centre for Sustainable Process Technology (CESPRO), Faculty of Engineering and Built Environment, Universiti Kebangsaan Malaysia, 43600 UKM Bangi, Selangor, Malaysia \\ ${ }^{2}$ Institute of Systems Biology, Universiti Kebangsaan Malaysia, 43600 UKM Bangi, Selangor, Malaysia \\ ${ }^{3}$ Tasik Chini Research Centre, Faculty of Science and Technology, Universiti Kebangsaan Malaysia, 43600 UKM Bangi, Selangor, Malaysia \\ *Corresponding Author Email : mohdaidilkamaruzzaman@yahoo.com}

Edited by

Prof. Ahmed Jalal Khan Chowdhury

Reviewed by

Dr. J. Wen

Dr. L. Su Shiung

\section{Abstract}

Aim: This research aimed to evaluate three $\mathrm{Cr}(\mathrm{VI})$-resistant rhizosphere bacteria (Bacillus cereus, Bacillus aerius and Exiguobacterium profundum) for their ability to produce plant growth-promoting (PGP) substances and to remove $\mathrm{Cr}(\mathrm{VI})$.

Methodology: Three rhizosphere bacteria were characterized for their ability to produce several PGP substances, including ammonia and indole-3-acetic acid (IAA) and solubilized phosphate. The $\mathrm{Cr}(\mathrm{VI})$ reduction ability of the rhizosphere bacteria was determined by diphenylcarbazide method with $60 \mathrm{mg} \mathrm{I}^{-1}$ $\mathrm{Cr}(\mathrm{VI})$.

Results: Bioreduction of $\mathrm{Cr}(\mathrm{VI})$ in the reduction media by $B$. cereus was $13.7 \%$, which was higher compared with those of $B$. aerius (4.4\%) and E. profundum (3.6\%). B. aerius adsorbed high $\mathrm{Cr}(\mathrm{VI})$ concentration of $56.1 \mathrm{mg} \mathrm{g}^{-1}$. The best condition for these rhizobacteria to remove or adsorb $\mathrm{Cr}(\mathrm{VI})$ was at acidic $\mathrm{pH}(5.36-5.97)$. All rhizobacteria could not stand the toxic effect of $\mathrm{Cr}(\mathrm{VI})$ at $60 \mathrm{mg} \mathrm{l}^{-1}$, which decreased almost $100 \%$ of rhizobacteria growth. B. cereus and B. aerius produced PGP substances, including ammonia and IAA and solubilized phosphate.

Interpretation: $B$. cereus and $B$. aerius with high PGP activities can be considered promising agents in microbe-assisted phytoremediation. All rhizosphere bacteria tolerated $\mathrm{Cr}(\mathrm{VI})$ and protected plants against the inhibitory effect of $\mathrm{Cr}(\mathrm{VI})$ by reducing $\mathrm{Cr}(\mathrm{VI})$ to $\mathrm{Cr}(\mathrm{III})$ and assisting the plant uptake of $\mathrm{Cr}(\mathrm{III})$.

Keywords : Bioreduction, Hexavalent chromium, Plant growth-promoting rhizobacteria, Rhizobacteria, Scirpus grossus

Ability of $\mathrm{Cr}(\mathrm{VI})$-resistant rhizosphere bacteria

\begin{tabular}{lcccc} 
& & & \\
& B. cereus & B. aerius & E. profundum \\
& & & \\
\hline & & & \\
$\mathrm{NH}_{3}$ production & $\checkmark$ & $\checkmark$ & $\checkmark$ \\
\hline P solubilization & $\checkmark$ & $\checkmark$ & $\checkmark$ \\
\hline IAA Production & $\checkmark$ & 4.4 & 3.6 \\
\hline $\mathrm{Cr}(\mathrm{VI})$ Reduction (\%) & 13.7 & 56.1 & 8.1 \\
\hline $\mathrm{Cr}(\mathrm{VI})$ biosorption (mg g-1) & 4.3 & 99.8 & 99.9 \\
\hline $\mathrm{CFU}$ reduction (\%) & 99.9 & $5.34-5.97$ & $5.34-5.97$ \\
\hline Optimum pH to remove Cr(VI) & $5.34-5.97$ & &
\end{tabular}

Citation: Kamaruzzaman, Mohd. A., S.R.S. Abdullah, H.A. Hasan, M. Hassan and M. Idris: Potential of hexavalent chromium-resistant rhizosphere bacteria in promoting plant growth and hexavalent chromium reduction. J. Environ. Biol., 40, 427-433 (2019). 


\section{Introduction}

Environmental pollution of chromium has become a major concern nowadays. Chromium application in industrial processes, including metallurgy, tanning and textile industry, has led to serious groundwater and soil pollution (Augustynowicz et al., 2010; Singh et al., 2010; Razali and Said, 2017). Chromium at high concentrations is mutagenic, teratogenic and carcinogenic, and can pose toxic effects on both plants and animals. The effects of chromium are magnified when it is in the form of $\mathrm{Cr}(\mathrm{VI})$, which is more reactive, mobile and toxic than $\mathrm{Cr}(\mathrm{III})$, which is less soluble in water (Redondo-Gomez et al., 2011; Paiva et al., 2009; Halim and Phang, 2017).

Previous studies have treated $\mathrm{Cr}(\mathrm{VI})$ pollution using many conventional techniques, including chemical reduction, electrochemical reduction, membrane filtration and ion exchange. However, the applications and performance of these methods are often limited by their high operation costs, large required quantities of sludge or ineffectiveness (Ton et al., 2015; $\mathrm{Li}$ et al., 2018). Compared with conventional treatment, phytoremediation treatment yields better results, has cheaper operation costs, and is more environmental friendly.

Phytoremediation is a green technology where plants are utilized to remove and make pollutants harmless or decrease toxicity from the environment (Anh et al., 2011; He et al., 2013; Ali et al., 2013; Lu et al., 2018). This technology involves plant-microbe interactions to remediate inorganic pollutants, especially heavy metals (Monferran et al., 2011). Plants play important role in phytoremediation through absorption, translocation, transformation and accumulation of heavy metals from the environment within their cells (Santana et al., 2012 Grijalbo et al., 2013). Prado et al. (2009) reported several plant species, such as Eichhornia crassipes, Typha latifolia, Carexlurida, Prosopis spp., Allium sativum, Leptospermum scoparium and Polypogon monspeliensis, have ability to reduce high percentage of $\mathrm{Cr}(\mathrm{VI})$ to $\mathrm{Cr}(\mathrm{III})$ and are excellent hyperaccumulators of $\mathrm{Cr}$. Microbes also play a crucial role in soil ecosystems by maintaining biogeochemical cycles and plant productivity (Prado et al., 2009; He et al., 2016). Plant growthpromoting rhizobacteria (PGPR) have recently attracted considerable attention because of their ability to enhance plant growth, protection against pathogen infection and reduce the effects of toxic stresses, leading to increased biomass of plants (Son et al., 2014; Rozainyet al., 2017). PGPR produce PGP substances, such as indole-3-acetic acid (IAA) and ammonia and solubilize phosphate to promote plant growth and improve total metal uptake (Orhan, 2016).

Scirpus grossus is a native wetland plant that can survive in contaminated sites (Tangahu et al., 2013; Al-Baldawi et al., 2015; Ismail et al., 2017; Yusoff et al., 2019). S. grossusis is a perennial tropical aquatic plant commonly known as giant bulrush, greater club-rush and rumput menderong (Malaysia), mensiang and walingi (Indonesia) (Tanghuet al., 2013; De'nanet al., 2017). Previous phytotoxicity studies reported that $S$. grossus can survive $\mathrm{Cr}(\mathrm{VI})$ concentrations up to $50 \mathrm{ppm}$ within 90 days of exposure and remove $98 \%$ total $\mathrm{Cr}$ and $84 \% \mathrm{Cr}(\mathrm{VI}$ ) (data not published). Therefore, the present study aimed to characterize and evaluate the potential of PGPR isolated from $S$. grossus to promote plant growth and remove $\mathrm{Cr}(\mathrm{VI})$.

\section{Materials and Methods}

Bioreduction of $\mathrm{Cr}(\mathrm{VI})$ by PGPR: Culture condition and inoculum preparation: Three Cr-resistance rhizosphere bacteria were isolated, screened, characterized and identified as Bacillus cereus, Bacillus aerius and Exiguobacterium profundum from a previous study (data not published). A fresh single culture was cultivated overnight at $37^{\circ} \mathrm{C}$ in trypticase soy broth with agitation at $150 \mathrm{rpm}$ (PROTECH S1-100D). After reaching the stationary phase, the cells were harvested and centrifuged at 4000 rpm for $15 \mathrm{~min}$ (Eppendorf Centrifuge 5810, Germany). The cell pellets were washed with aqueous solution to remove any residues adsorbed on the cell surfaces. The initial inoculum concentration was inoculated to an $\mathrm{OD}_{550}$ of 0.5 (HACH DR6000, USA).

$\mathrm{Cr}(\mathrm{VI})$ stock solution: The reduction of $\mathrm{Cr}(\mathrm{VI})$ was studied in an aqueous solution. $\mathrm{Cr}(\mathrm{VI})$ stock solution was prepared by dissolving analytical-grade $\mathrm{K}_{2} \mathrm{Cr}_{2} \mathrm{O}_{7}(1 \mathrm{~g}$, SYSTERM, Malaysia) in 1 I of distilled water and mixing until complete dissolution. $\mathrm{Cr}(\mathrm{VI})$ spiked medium was prepared by diluting this solution to the required concentration $\left(60 \mathrm{mgl}^{-1}\right)$ in the reduction media.

Bioreduction experiments: Bioreduction medium was prepared by using aqueous solution and spiked with an initial $\mathrm{Cr}(\mathrm{VI})$ concentration of $60 \mathrm{mg} \mathrm{l}^{-1}$. A $20 \mathrm{ml}$ aliquot of the PGPR inoculum with OD 0.5 was added into $400 \mathrm{ml}$ of bioreduction media (10\% $\mathrm{v} / \mathrm{v}$ ) and performed under sterile condition. The sample was incubated from Day 0 to Day 5 under shaking at $150 \mathrm{rpm}$ and 37 ${ }^{\circ} \mathrm{C}$ (PROTECH S1-100D). Liquid samples of $10 \mathrm{ml}$ were removed daily and centrifuged at $4000 \mathrm{rpm}$ for $15 \mathrm{~min}$ (Eppendorf Centrifuge 5810 , Germany). The $\mathrm{pH}$ of the supernatant was recorded ( $\mathrm{HACH}$ sensION+, USA), and the remaining $\mathrm{Cr}(\mathrm{VI})$ was analyzed using the 1,5-diphenylcarbohydrazide method (Gnanamani et al., 2010) at an absorbance of $540 \mathrm{~nm}$ with a UV spectrophotometer (HACH DR6000, USA). Pellet cell was naturally dried within 2 days and diluted to 1:1:3 (nitric acid: $\mathrm{H}_{2} \mathrm{O}_{2}$ : Dl water) within $24 \mathrm{hr}$ at room temperature (Tangahu et al., 2013). The digested $\mathrm{Cr}(\mathrm{VI})$ concentration was measured by 1,5diphenylcarbohydrazide method.

Determination of rhizosphere bacteria population: The number of colony-forming units (CFUs) was performed using the standard plate count method on Day 0, Day 2 and final day of exposure (Day 5). Serial dilutions were prepared in duplicate, and 


\section{$0.1 \mathrm{ml}$ of each dilution was spread onto trypticase soy agar.}

Plant growth-promoting activities: The following PGP abilities were determined as previously described by Orhan (2016) and Khan et al. (2017).

Ammonia production: For assessing the ability to produce ammonia, fresh culture was added to peptone water (Peptone 20 $\mathrm{gl}^{-1}$ and $\mathrm{NaCl} 30 \mathrm{gl}^{-1}$ ) and incubated at $30^{\circ} \mathrm{C}$ with constant shaking at $140 \mathrm{rpm}$ for 5 days. After incubation, $0.2 \mathrm{ml}$ of the culture supernatant was mixed with $1 \mathrm{ml}$ of Nessler's reagent (Anees et al., 2017). The OD of the mixture was measured at $450 \mathrm{~nm}$ using a UV spectrophotometer (HACH DR6000, USA), and development of yellow to brown color was considered as a positive result for ammonia production.

Phosphate solubilization ability: For phosphate solubilization assay, fresh culture was inoculated with Pikovskaya's modified medium and incubated at $30^{\circ} \mathrm{C}$ for 7 days. Pikovskaya's modified medium contained the following per liter: glucose, $10 \mathrm{~g}$; Ca3(PO4)2, 5 g; (NH4)2SO4, 0.5 g; MgSO4.7H2O, $0.1 \mathrm{~g} ; \mathrm{KCl}$, $0.2 \mathrm{~g}$; yeast extract, $0.5 \mathrm{~g} ; \mathrm{MnSO} 4 \cdot \mathrm{H} 2 \mathrm{O}, 0.002 \mathrm{~g} ; \mathrm{FeSO} \cdot 7 \mathrm{H} 2 \mathrm{O}$, $0.002 \mathrm{~g} ; \mathrm{NaCl}, 30.0 \mathrm{~g}$; and agar, $15 \mathrm{~g}$. Development of clearance zone on Pikovskaya's agar was considered positive for phosphate solubilization.

IAA production: The IAA concentration produced by each isolate was determined according to Salkowski's colorimetric method. Each bacterial culture was grown in a nutrient broth medium containing $0.1 \mathrm{mg} \mathrm{ml}^{-1}$ I-tryptophan and $5 \% \mathrm{NaCl}$ and then incubated at $30^{\circ} \mathrm{C}$ for $2-4$ days. After incubation, the broth was centrifuged, the supernatant was retained, and $1 \mathrm{ml}$ of the supernatant was mixed with $2 \mathrm{ml}$ of Salkowski's reagent (2\% 0.5 $\mathrm{FeCl}_{3}$ in $35 \% \mathrm{HCLO}_{4}$ solution) and stored in dark for a minimum of $30 \mathrm{~min}$. After $30 \mathrm{~min}$ in dark, the absorbance was read at $530 \mathrm{~nm}$ (HACH DR6000, USA). The IAA concentration was determined using a calibration curve of pure IAA as standard.

Statistical analysis: All analyses were performed using SPSS version 16.0 (IBM, USA). The effects of $\mathrm{Cr}(\mathrm{VI})$ concentrations on bioreduction and CFU were analyzed using one-way ANOVA. DMRT was used to evaluate differences between all parameters at $95 \%$ confidence limit $(p<0.05)$, unless otherwise stated. Sampling and analyses were performed in triplicate.

\section{Results and Discussion}

Fig. 1 shows the result of $\mathrm{Cr}(\mathrm{VI})$ reduction abilities of three rhizobacteria ( $B$. cereus, $B$. aerius and $E$. profundum) in reduction media spiked with $60 \mathrm{mg} \mathrm{l}^{-1} \mathrm{Cr}(\mathrm{VI})$. Bioreduction of $\mathrm{Cr}(\mathrm{VI})$ in the reduction media by $B$. cereus was $13.7 \%$, which was higher compared with those of $B$. aerius (4.4\%) and $E$. profundum (3.6\%) (Table 1). The study on the biosorption of $\mathrm{Cr}(\mathrm{VI})$ within rhizobacteria cells showed that only $B$. aerius could adsorb high $\mathrm{Cr}(\mathrm{IV})\left(56.1 \mathrm{mg} \mathrm{g}^{-1}\right)$ after 5 days of exposure, whereas $B$. cereus and $E$. profundum adsorbed 4.3 and $8.1 \mathrm{mg} \mathrm{g}^{-1}$, respectively (Fig. 2). A previous study reported that $B$. cereus could reduce $\mathrm{Cr}(\mathrm{VI})$ with initial concentrations of 60 and $70 \mathrm{mg} \mathrm{I}^{-1}$ by up to $96.7 \%$ and 72.1\%, respectively (Murugavelh et al., 2013; Shaikh et al., 2017).

The effect of bioreduction of $\mathrm{Cr}(\mathrm{VI})$ on the $\mathrm{pH}$ of the reduction media was also examined. The $\mathrm{pH}$ was acidic $\mathrm{pH}$

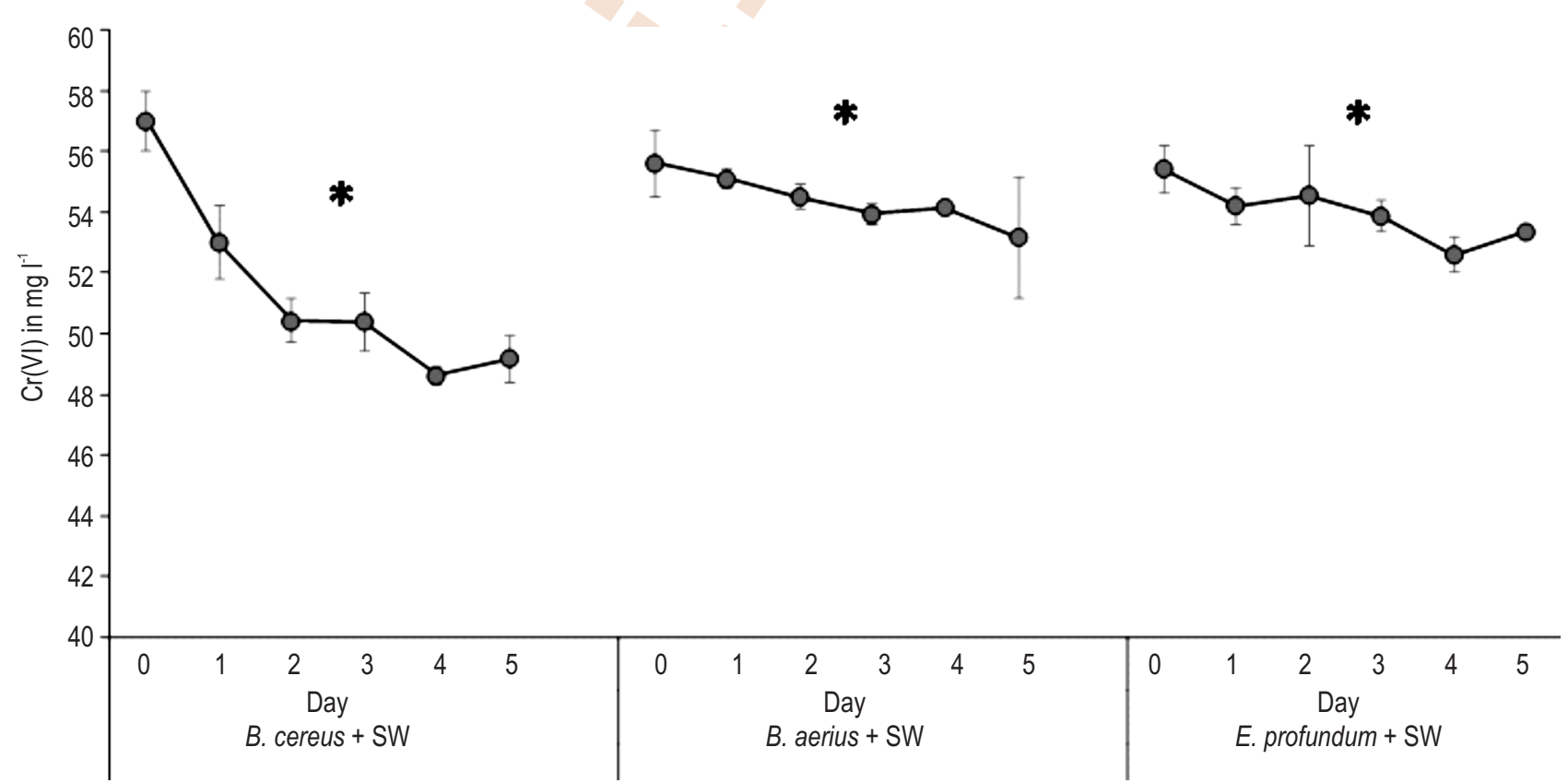

Fig. 1 : $\mathrm{Cr}(\mathrm{VI})$ in reduction media by $B$. cereus, B. aerius and $E$. profundum with an initial concentration of $60 \mathrm{mg} \mathrm{I}^{-1} \mathrm{Cr}(\mathrm{VI})(\mathrm{SW}=$ saline water $){ }^{*}$ represents statistically significant differences in $\mathrm{Cr}(\mathrm{VI})$ reduction for each rhizobacteria $(p<0.05)]$. 




Fig. 2 : Biosorption of $\mathrm{Cr}(\mathrm{VI})$ by B. cereus, B. aerius and E. profundum cells [ ${ }^{\star}$ represents statistically significant differences in the biosorption of $\mathrm{Cr}(\mathrm{VI})$ for each rhizobacteria $(p<0.05)]$.

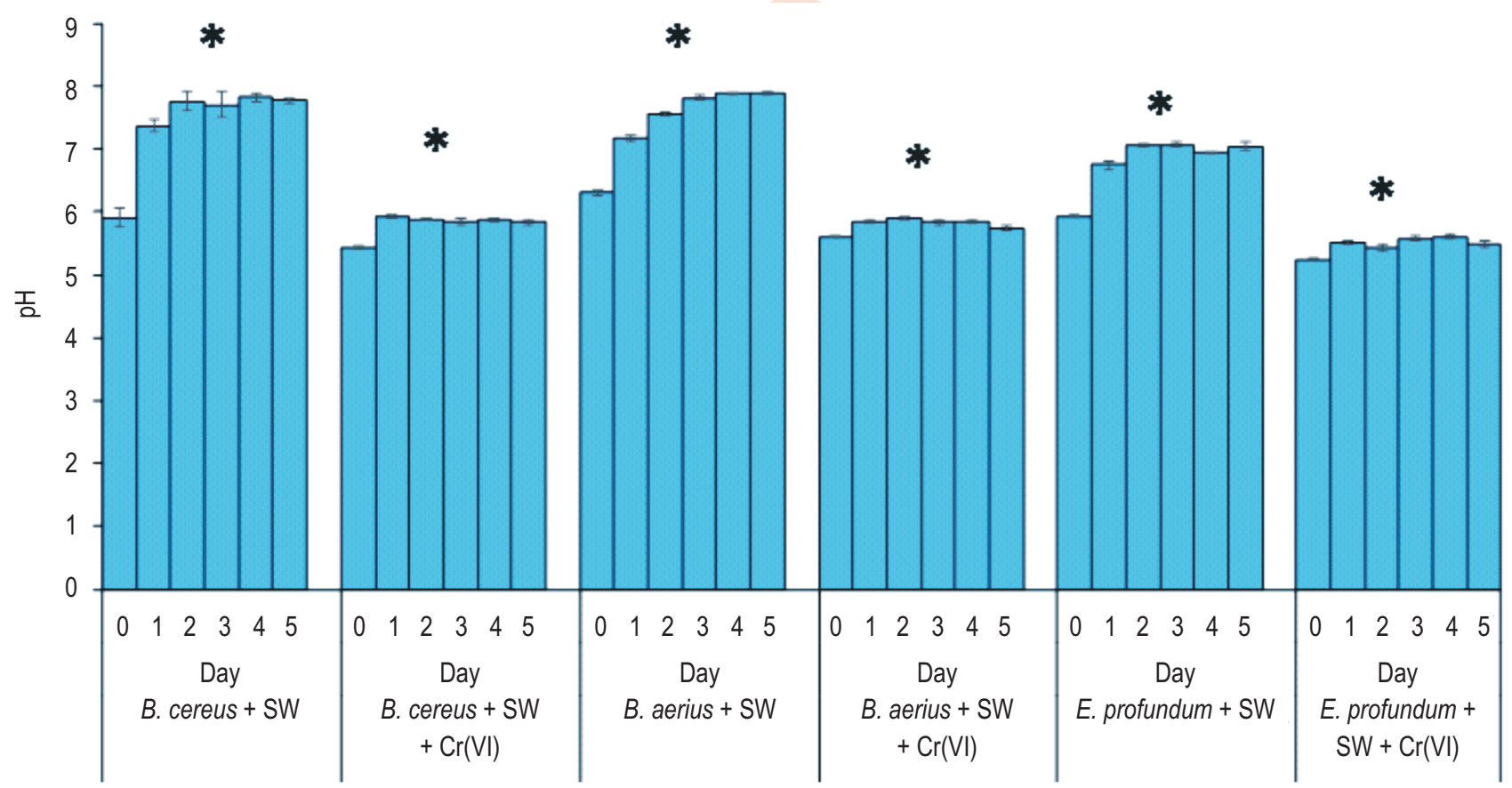

Fig. 3 : Effect of $\mathrm{Cr}(\mathrm{VI})$ reduction on $\mathrm{pH}$ in saline water with an initial concentration of $60 \mathrm{mg} \mathrm{I}^{-1} \mathrm{Cr}(\mathrm{VI})\left[^{\star}\right.$ represents statistically significant differences in $\mathrm{pH}$ between control and presence of $\mathrm{Cr}(\mathrm{VI})$ for each rhizobacteria $(p<0.05)]$.

5.34-5.97) in all three rhizobacteria with an initial concentration of $60 \mathrm{mg} \mathrm{l}^{-1} \mathrm{Cr}(\mathrm{VI})$ (Fig. 3). Compared with the $\mathrm{pH}$ of the reduction media without $\mathrm{Cr}(\mathrm{VI})$, the media with $\mathrm{Cr}(\mathrm{VI})$ had neutral $\mathrm{pH}$ (6.88-7.93). Similarly, a previous study reported that $\mathrm{pH} 6$ is the 


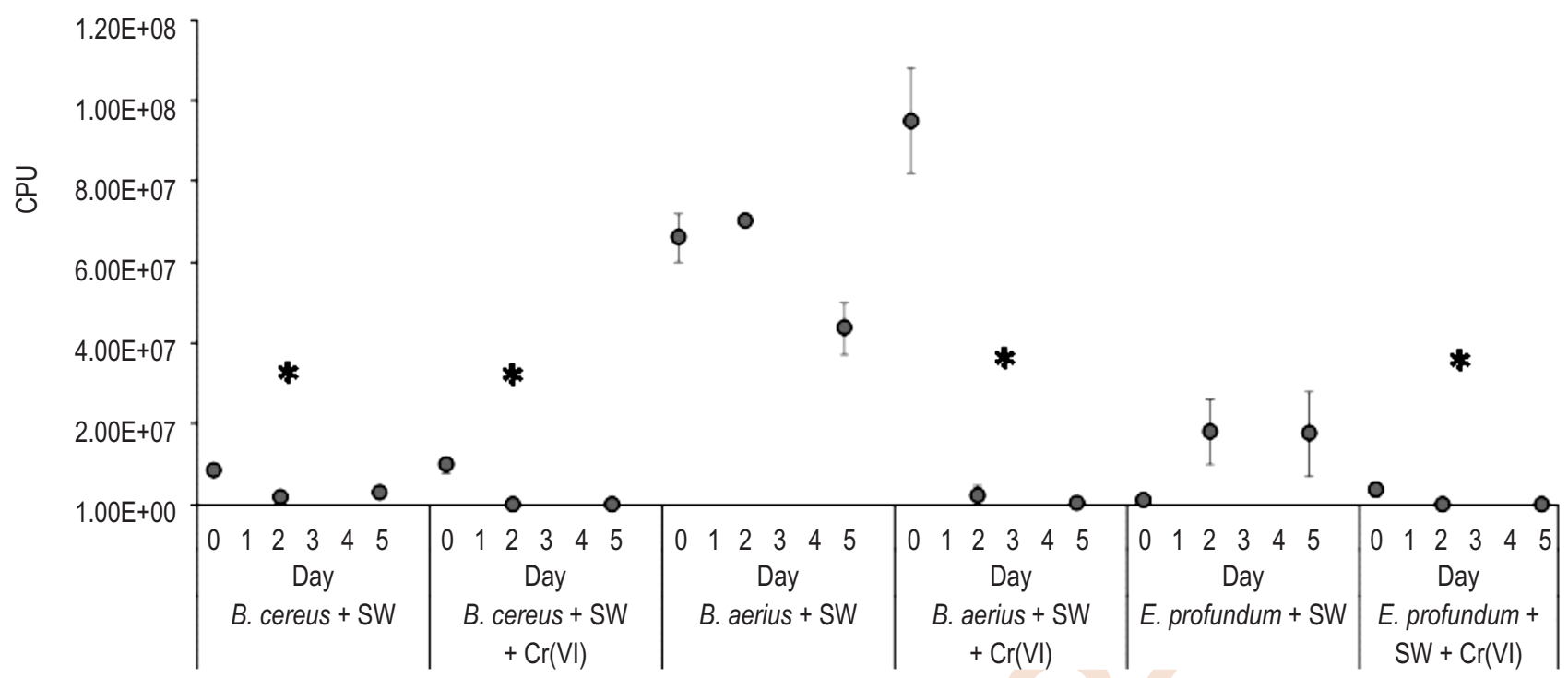

Fig. 4 : Rhizobacteria population in $\mathrm{Cr}(\mathrm{VI})$ reduction medium [ ${ }^{*}$ represents statistically significant differences in CFU for each rhizobacteria $\left.(p<0.05)\right]$.

Table 1: Characterization of rhizosphere bacteria for plant growth-promoting activities and ability to reduce $\mathrm{Cr}(\mathrm{VI})$

\begin{tabular}{|c|c|c|c|c|c|c|c|}
\hline \multirow[t]{2}{*}{$\begin{array}{l}\text { Heavy } \\
\text { metal }\end{array}$} & \multirow[t]{2}{*}{ Rhizobacteria } & \multicolumn{3}{|c|}{ Plant Growth-Promoting Activities } & \multirow{2}{*}{$\begin{array}{l}\mathrm{Cr}(\mathrm{VI}) \\
\text { Reduction (\%) } \\
\text { Reduction media }\end{array}$} & \multirow{2}{*}{$\begin{array}{l}\mathrm{Cr}(\mathrm{VI}) \\
\text { Biosorption }\left(\mathrm{mg} \mathrm{g}^{-1}\right) \\
\text { Cell }\end{array}$} & \multirow{2}{*}{$\begin{array}{l}\text { CFU } \\
\text { Reduction } \\
(\%)\end{array}$} \\
\hline & & $\mathrm{NH}_{3}$ & P Solubilization & IAA & & & \\
\hline \multirow[t]{3}{*}{$\mathrm{Cr}(\mathrm{VI})$} & B. cereus & + & + & + & 13.7 & 4.3 & 99.9 \\
\hline & B. aerius & + & + & + & 4.4 & 56.1 & 99.8 \\
\hline & E. profundum & + & - & + & 3.6 & 8.1 & 99.9 \\
\hline
\end{tabular}

optimum for the reduction of $\mathrm{Cr}(\mathrm{VI})$ with $B$. cereus (Murugavelh and Mohanty, 2012). pH is an important parameter that affects $\mathrm{Cr}(\mathrm{VI})$ solubility and bacterial growth in wastewater treatment (Murugavelh and Mohanty, 2012). Rhizosphere microbes can reportedly improve metal solubility and availability by reducing the soil $\mathrm{pH}$ or by producing chelators and siderophores, which could enhance heavy metal extraction by plants (Rajkumar et al., 2012; Islam et al., 2014; Cho, 2017).

The effect of $\mathrm{Cr}(\mathrm{VI})$ reduction on rhizobacteria growth is shown in Fig. 4. The growth of each rhizobacteria reduced nearly to $100 \%$ CFU reduction at a $\mathrm{Cr}(\mathrm{VI})$ concentration of $60 \mathrm{mg} \mathrm{l}^{-1}$ (Table 1). In addition, the growth of rhizobacteria reduced drastically due to toxic effect of $\mathrm{Cr}(\mathrm{VI})$ compared with the control (Without $\mathrm{Cr}(\mathrm{VI})$ ). A previous study reported that $\mathrm{Cr}(\mathrm{VI})$ may reduce microbial biomass completely, decrease specific population, or even cause shifts in microbial community structure even with a small amount of heavy metal (Zhuang et al., 2007).

Table 1 summarizes the ability of each rhizobacteria to reduce $\mathrm{Cr}(\mathrm{VI})$ and the potential to produce PGP substances. $B$. cereus and $B$. aerius could produce more PGP substances, whereas $E$. profundum was not able to solubilize phosphate.
From the perspective of $\mathrm{Cr}(\mathrm{VI})$ reduction, $B$. cereus showed greater ability to produce PGP substances and reduce $\mathrm{Cr}(\mathrm{VI})$ than $B$. aerius. These results also prove that all rhizobacteria are not only resistant to high concentrations of $\mathrm{Cr}(\mathrm{VI})$ but also serve different functions within the rhizobacteria community. However, not all rhizobacteria can reduce toxicity and promote plant growth simultaneously. Each species of rhizobacteria has its inherent participation in plant-microbe interaction to survive toxicity. Hardoim et al. (2008) reported that the presence of associated bacteria in phytoremediation can benefit both parties, i.e., plants can grow better, suffer less stress, solubilize macronutrients and establish in different ecosystems whereas microbes can benefit from nutrient availability from plants.

Bioreduction of $\mathrm{Cr}(\mathrm{VI})$ at an initial concentration of $60 \mathrm{mg} \mathrm{l}^{-1}$ in the reduction media by $B$. cereus was $13.7 \%$, which was higher compared with that of $B$. aerius (4.4\%) and $E$. profundum (3.6\%). $B$. aerius could adsorb high $\mathrm{Cr}(\mathrm{VI})$ concentration of $56.1 \mathrm{mg} \mathrm{g}^{-1}$. The best condition for these rhizobacteria to remove or adsorb $\mathrm{Cr}(\mathrm{VI})$ was at acidic $\mathrm{pH}(5.0-6.0)$. $\mathrm{Cr}(\mathrm{VI})$ was highly toxic to rhizobacteria and thus drastically reduced their growth. Both $B$. cereus and $B$. aerius could produce PGP substances, including ammonia and IAA, and solubilize phosphate. Although some 
$\mathrm{Cr}(\mathrm{VI})$-resistant rhizobacteria could not reduce $\mathrm{Cr}(\mathrm{VI})$ or produce PGP substances, all of them serve inherent functions to maintain the sustainability of plant growth and health while enhancing phytoremediation.

\section{Acknowledgment}

The authors would like to thank Universiti Kebangsaan Malaysia for supporting this research project under Grant No. MI2018-003

\section{References}

Al-Baldawi, I.A., S.R.S. Abdullah, N. Anuar, F. Suja and M. Idris: Phytodegradation of total petroleum hydrocarbon (TPH) in dieselcontaminated water using Scirpus grossus. Ecol. Eng., 74, 463-473 (2015).

Ali, H., E. Khan and M.A. Sajad: Phytoremediation of heavy metals concepts and applications. Chemosphere, 91, 869-881 (2013).

Anees, M.M., M. Qasim and A. Bashir: Physiological and physical impact of noise pollution on environment. Earth Sci. Pak., 1, 08-10 (2017).

Anh, B.T.K., D.D. Kim, T.V. Tua, N.T. Kien and D.T. Anh: Phytoremediation potential of indigenous plants from Thai Nguyen province, Vietnam. J. Environ. Biol., 32, 257-262 (2011).

Augustynowicz, J., M. Grosicki, E. Hanus-Fajerska, M. Lekka, A Waloszek and $\mathrm{H}$. Kołoczek: Chromium(VI) bioremediation by aquatic macrophyte Callitriche cophocarpa Sendtn. Chemosphere, 79, 1077-1083(2010).

Cho, T.: Innovative micro-dust reduction technologies. Acta Chemica Malaysia, 1, 04-07(2017)

De'nan, F., N. Naaim and L.C. Leong: Behaviour of flush end-plate connection for perforated section. Eng. Herit. J., 1, 11-20(2017).

Gnanamani, A., V. Kavitha, N. Radhakrishnan, G.S. Rajakumar, G. Sekaran and A. B. Mandal: Microbial products (biosurfactant and extracellular chromate reductase) of marine microorganism are the potential agents reduce the oxidative stress induced by toxic heavy metals. Colloids Surf. B., 79, 334-339 (2010).

Grijalbo, L., M.F. Pascual, D.G. Seco, F.J.G. Manero and J.A. Lucas: Spent metal working fluids produced alterations on photosynthetic parameters and cell-ultrastructure of leaves and roots of maize plants. J. Hazard. Mater., 260, 220-230(2013).

Halim, N.I.A. and I.C. Phang: Salicylic acid mitigates $\mathrm{Pb}$ stress in Nicotiana tabacum. Sci. Herit. J., 1, 16-19 (2017)

Hardoim, P.R., I.S.V. Overbeek and J.D.V. Elsas: Properties of bacteria endophytes and their proposed role in plant growth. Trends Microbiol., 16, 463-471 (2008)

He, H., Z. Ye, D. Yang, J. Yan, L. Xiao, T. Zhong, M. Yuan and X. Cai: Characterization of endophytic Rahnella sp. JN6 from Polygonum pubescens and its potential in promoting growth and $\mathrm{Cd}, \mathrm{Pb}, \mathrm{Zn}$ uptake by Brassica napus. Chemosphere, 90, 1960-1965 (2013).

He, Z., Y. Hu, Z. Yin, Y. Huand H. Zhong: Microbial diversity of chromiumcontaminated soils and characterization of six chromiumremoving bacteria. Environ. Manage., 57, 1319-1328 (2016).

Islam, F., T. Yasmeen, Q. Ali, S. Ali, M.S. Arifa, S. Hussain and H. Rizvi: Influence of Pseudomonas aeruginosa as PGPR on oxidative stress tolerance in wheat under Zn stress. Ecotoxicol. Environ Saf., 104, 285-293(2014).

Ismail, N.I., S.R.S. Abdullah, M. Idris, H.A. Hasan, M.I.E. Halmi, N.H.A.
Sbani, O.H. Jehawi, S.N.A. Sanusi and M.H. Hashim: Accumulation of Fe-Al by Scirpus grossus grown in synthetic bauxite mining wastewater and identification of resistant rhizobacteria. Env. Eng. Sci., 34, 367-375(2017).

Khan, A., R. Rehman, H. Rashid and A. Nasir: Exploration of environmental friendly adsorbents for treatment of azo dyes from textile wastewater and its dosage optimization. Earth Sci. Pak., 1, 05-07(2017)

Li, Y., P. Yang and H. Wang: Collecting coal fired power environmental tax to promote wind power development and environmental improvement. Acta Sci. Malays., 2, 05-08 (2018).

Lu, Z., X. Daxing and W. Hailun: Two-stage cubature kalman filter and its application in water pollution model. Acta Sci. Malays., 2, 09-13 (2018).

Monferrán, M.V., M.L. Pignata and D.A. Wunderlin: Enhanced phytoextraction of chromium by the aquatic macrophyte Potamogeton pusillus in presence of copper. Environ. Pollut., 161, 15-22 (2011).

Murugavelh, S. and K. Mohanty: Bioreduction of hexavalent chromium by free cells and cell free extracts of Halomonas sp. Chem. Eng. J., 203, 415-422 (2012)

Murugavelh, S. and K. Mohanty: Isolation, identification and characterization of $\mathrm{Cr}(\mathrm{VI})$ reducing Bacillus cereus from chromium contaminated soil. Chem. Eng. J., 230, 1-9(2013).

Orhan, F.: Alleviation of salt stress by halotolerant and halophilic plant growth-promoting bacteria in wheat (Triticum aestivum). Braz. J. Microbiol., 47, 621-627 (2016).

Paiva, L.B., J.G.D. Oliveira, R.A. Azevedo, D.R. Ribeiro, M.G.D. Silva and A.P. Vitória: Eco physiological responses of water hyacinth exposed to $\mathrm{Cr}^{3+}$ and $\mathrm{Cr}^{6+}$. Environ. Exper. Bot., 65, 403-409 (2009).

Prado, C., L.R. Montelongo, J.A. Gonzalez, E.A. Pagano, M. Hilal and F.E. Prado: Uptake of chromium by Salvinia minima: Effect on plant growth, leaf respiration and carbohydrate metabolism. J. Hazard. Mater., 177, 546-553 (2009).

Rajkumar, M., S. Sandhya, M.N.V. Prasad and H. Freitas: Perspectives of plant-associated microbes in heavy metal phytoremediation. Biotechnol. Adv., 30, 1562-1574 (2012).

Razali, M.A.A. and F.M. Said: Red pigment production by Monascus purpureus in stirred-drum bioreactor. Sci. Herit. J., 1, 13-15 (2017).

Redondo-Gómez, S., E. Mateos-Naranjo, I. Vecino-Bueno and S.R. Feldman: Accumulation and tolerance characteristics of chromium in a cordgrass Cr-hyperaccumulator, Spartina argentinensis. J. Hazard. Mater., 185, 862-869 (2011).

Rozainy M.R., W.W. Khairi, I. Abustan, S.S. Rahim, M.N.N. Khan and N.K.E.M Yahaya: Comparison method of odour impact evaluation using CALPUFF dispersion modelling and on-site odour monitoring. Eng. Herit. J., 1,06-10(2017).

Santana, K.B., A.A.F.D. Almeida, V.L. Souza, P.A.O. Mangabeira, D.D.C. Silva, F.P. Gomes, L. Dutruch and L.L. Loguercio: Physiological analyses of Genipa americana $L$. reveals a tree with ability as phytostabilizer and rhizofilterer of chromium ions for phytoremediation of polluted watersheds. Environ. Exper. Bot., 80, 35-42 (2012)

Shaikh, M.M., A.O. AlSuhaimi, M.M. Hanafiah, M.A. Ashraf, A. Fantoukh and E. AlHarbi: Leachable volatile organic compounds from polyethylene plumbing plastic pipes: A case study of Medina Al Munawarah, SaudiArabia. Acta Chem. Malay., 1, 01-03(2017).

Singh, N.K., U.N. Rai, M. Singh and R.D. Tripathi. Impact of rhizobacteria 
on growth and chromium accumulation in Scirpus lacustris L. grown under chromium supplementation. J. Environ. Biol., 31, 709-704 (2010).

Son, J.S., M. Sumayo, Y.J. Hwang, B.S. Kim and S.Y. Ghim: Screening of plant growth-promoting rhizobacteria as elicitor of systemic resistance against gray leaf spot disease in pepper. Appl. Soil Ecol., 73, 1-8 (2014).

Tangahu, B.V., S.R.S. Abdullah, H. Basri, M. Idris, N. Anuar and M. Mukhlisin: Phytotoxicity of wastewater containing lead $(\mathrm{Pb})$ effects Scirpus grossus. Int. J. Phytoremediation, 15, 814-826 (2013).

Tangahu, B.V., S.R.S. Abdullah, H. Basri, M. Idris, N. Anuar and M. Mukhlisin: Biosorption of lead (Pb) by three Bacillus species (Bacillus cereus, Bacillus pumilus and Bacillus subtilis) isolated from Scirpus grossus. from sources to solution. In: Proceedings of the International Conference on Environmental Forensics 2013 (Eds.: A.Z. Aris, T.H. Tengku Ismail, R. Harun, A.M. Abdullah and M.Y. Ishak) pp. 215-220 (2013).

Ton, S.S., M.W. Lee, Y.H. Yang, S.K. Hoi, W.C. Cheng, K.S. Wang, H.H. Chang and S.H. Chang: Effects of reductants on phytoextraction of chromium (VI) by Ipomoea aquatic. Int. J. Phytoremediation, 17, 429-436 (2015).

Yusoff, M.F.M, S.R.S. Abdullah and H.A. Hasan: Performance of continuous pilot subsurface constructed wetland using Scirpus grossus for removal of COD, colour and suspended solid in recycled pulp and paper effluent. Environ. Technol. Innov., 13, 346352 (2019).

Zhuang, X., J. Chen, H. Shim and Z. Bai: New advances in plant growthpromoting rhizobacteria for bioremediation. Env. Int., 33, 406-413 (2007). 